\title{
Konaklama İşletmelerindeki Liderlik Davranış Türlerinin Örgütsel Sessizlik, Örgütsel Sinizm ve Psikolojik İyi Oluşa Etkisi: Türkiye ve İtalya Üzerine Bir Çalışma
}

\author{
Ayşe ATAR, Gazi Üniversitesi, Sosyal Bilimler Enstitüsü, Doktora Öğrencisi, e-posta: \\ aysee1@gazi.edu.tr \\ ORCID:https://orcid.org/0000-0002-9060-6684
}

Doç. Dr. Ece KONAKLIOĞLU, Gazi Üniversitesi, Turizm Fakültesi, Turizm İşletmeciliği Bölümü, e-posta: ece@gazi.edu.tr

ORCID: https://orcid.org/0000-0001-9326-1610

\section{Öz}

Bir işletmenin uyumlu bir biçimde çalışabilmesi ve etkin olabilmesi için iyi bir şekilde yönetilmesi gerekmektedir. Bu yönetim fonksiyonunu ise gerçekleştirecek olan yöneticidir. Yönetici liderlik davranışlarını etkili kullanıyor ve işgören bağlılığını önemsiyor ise başarıdan söz edilebilir. Bu bakış açısından yola çıkarak, çalışmanın amacı, etkileşimci ve dönüşümcü liderlik, örgütsel sessizlik, örgütsel sinizm ve psikolojik iyi oluş arasındaki ilişkiyi test etmek ve etki düzeylerini incelemektir. Çalışmanın evrenini Türkiye'de Antalya İtalya'da Amalfi Coast bölgesinde farklı merkezlerde faaliyet gösteren 4 ve 5 yıldızlı konaklama işletmeleri oluşturmaktadır. Evren içerisinden alınan örneklem ile Antalya bölgesinde 718 Amalfi Coast bölgesinde ise 357 toplamda seçilen 1075 çalışan personele anket uygulanmıştır. Araştırma sonuçlarına göre, etkileşimci ve dönüşümcü liderlik ile örgütsel sessizlik, örgütsel sessizlik ile örgütsel sinizm, örgütsel sinizm ile psikolojik iyi oluş arasında istatistiksel olarak anlamlı bir ilişki olduğu sonucuna ulaşılmıştır. Ayrıca bağımsız değişken olarak adlandırılan etkileşimci ve dönüşümcü liderliğin bağımlı değişken olan örgütsel sessizlik üzerinde anlamlı bir etkisi olduğu görülür iken, yine örgütsel sessizliğin örgütsel sinizmi, örgütsel sinizmin ise bağımlı değişken olan psikolojik iyi oluşa karşı anlamlı bir etkiye sahip olduğu sonucuna ulaşılmıştır. Bu bulgular sonucunda liderlerin sergilediği etkileşimci ve dönüşümcü liderlik tarzlarının yarattığı etkilerin olası sonuçları üzerinde önermelerde bulunulmuştur.

Anahtar Kelimeler: Liderlik, Örgütsel Sessizlik, Örgütsel Sinizm, Psikolojik İyi oluş, İtalya/Türkiye Konaklama İşletmeleri.

\section{Önerilen Atıf:}

Atar, A. ve Konaklığlu, E. (2018). Konaklama İşletmelerindeki Liderlik Davranış Türlerinin Örgütsel Sessizlik, Örgütsel Sinizm ve Psikolojik İyi Oluşa Etkisi: Türkiye ve İtalya Üzerine Bir Çalışma, Türk Turizm Araştırmaları Dergisi, Cilt.2, Sayı.3, ss.45-65. 


\title{
Effect of Leadership Styles in Hotels on Organizational Silence, Organizational Cynicism and Psychological Well-being.
}

Ayşe ATAR, Gazi University, Institute of Social Sciences, (Ph.D in Progress) e-mail: aysee1@gazi.edu.tr ORCID: https://orcid.org/0000-0002-9060-6684

Associate Prof. Dr. Ece KONAKLIOĞLU, Gazi University, Faculty of Tourism, e-mail: ece@gazi.edu.tr

ORCID: https://orcid.org/0000-0001-9326-1610

\begin{abstract}
An organization needs to be well managed to be able to work in harmony and be effective. This management function is the manager who will realize it. If the manager is using the leadership behaviors effectively and cares about his/her occupational commitment, it can be mentioned about successful. Starting from this point of view, the aim of this study is to analyze the relationship and to determine the effect levels of transactional, transportational leaderships on organizational silence, organizational cynicism and psychological wellbeing. The universe of present study is comprised of with 4 and 5 stars hotels which operate in different destinations both Turkey/Antalya and Italy/Amalfi Coast. 718 staff who work in Turkey/Antalya and 357 staff who work in Italy/Amalfi Coast were selected as sample of this study and the survey of this study were practiced to totally 1075 staff then the result of survey were assessed According to result of this study; the significant correlation between leadership styles, organizational silence, organizational cynicism and psychological well-being were detected. As a result of these findings, suggestions were made on the possible consequences of the effects created by the transactional and transformational leadership styles exhibited by the leaders.
\end{abstract}

Keywords: Leadership, Organizational silence, Organizational cynicism and Psychological wellbeing, Italy/Turkey hotel.

\section{Suggested Citation:}

Atar, A. and Konaklığlu, E. (2018). Effect of Leadership Styles in Hotels on Organizational Silence, Organizational Cynicism and Psychological Well-being, Journal of Turkish Tourism Research, Vol.2, Issue.3, pp.45-65. 


\section{GíRiş}

Hızlı değişimlerin ve yoğun rekabetin yaşandığı günümüzde liderlik kavramı eskisinden daha çok önem kazanmıştır. Liderlerin sergiledikleri liderlik davranışları ve bu konudaki başarıları, etkiledikleri grupların başarısını da beraberinde getirmektedir. Bugünkü şartlar göz önünde bulundurulduğunda ancak çalışanlarını ikna eden onlarla etkili iletişim içinde bulunup onları yeri geldiğinde karar verme aşamasında tutacak kadar önemseyen ve buna benzer yollarla da onları motive eden liderler işletmelerinde etkinlik sağlayıp sinerji oluşturabilirler. Çünkü bir işletmenin lider konumda olması, belirlediği stratejik amaçlar doğrultusunda nasıl yönetildiğine ve çalışanda yaratılan işletme algısına da bağlıdır.

Izgar'a (2008) göre işinde memnuniyetsizlik yaşayan birey, olumsuz duygular yaşar. Bu olumsuz duygular ise onu bedensel, ruhsal ve sosyal yönden negatif olarak etkiler ve birey o saatten sonra içinde bulunduğu şartlara uyum açısından zorluk yaşamaya başlayabilir. Bu uyum zorluğunun sonucunda çalışan personel de işten uzaklaşma, işi terk etme, işe karşı kayıtsızlık sürekli işten yakınma, mesleğin geleceğine ilişkin umutsuzluk düşünceleri gibi doyumsuzluk belirtileri gösterebilir. $\mathrm{Bu}$ belirtiler psikolojik ve sosyal temeller dışında yönetimsel açıdan değerlendirildiğinde, olumsuz liderlik davranışları yüzünden ortaya çıkan örgütsel sessizlik (Organizational Silence), örgütsel sinizm (Organizational Cynicism) ve psikolojik iyi oluş (Psychological Well-being) etkin örgütsel yapılanmanın oluşamaması (Stanley vd., 2005 verimliliği etkileyen davranış ve tutumların meydana gelmesine neden olabilir. Bu noktada çalışmanın kavramsal temellerini oluşturan örgütsel sessizlik, sinizm ve psikolojik iyi oluş kavramları ile liderlik arasındaki bağın anlaşılması açısından önem arz eder. Ayrıca, turizm sektöründe hem teoriye hem de uygulamaya katkı sağlayacağı düşüncesi ile bahsedilen değişkenler göz önüne alınarak yapılan bir çalışmaya daha önce rastlanılamaması bu araştırmanın yapılmasına karşı duyulan gereksinimi arttırmıs, yapılan çalışma ile birlikte, turizm işletmeciliği literatürü dışında, bahsedilen değişkenler literatüründe söz konusu boşluğun doldurulması amaçlanmıştır. Bu gerekçeler doğrultusunda çalışmanın temel amacı; yöneticinin göstermiş olduğu liderlik davranış türlerini, kavramsal açıdan ele alarak, bunların örgütsel sessizlik, örgütsel sinizm ve psikolojik iyi oluş ile olan ilişkisini incelemektir. Çalışmanın teorik amacının yanı sıra, turizm sektöründe çalışan lider konumundaki yöneticilere personellerine nasıl davranmaları, hangi davranış biçimlerini benimsedikleri takdirde bulundukları pazarda lider konumuna gelebilecekleri konusunda yol gösterici olmayı amaçlaması da çalışmanın uygulamaya dönük amaçları arasında yer almaktadır.

\section{KAVRAMSAL ÇERÇEVE}

Bir işletmede yöneticinin sergilediği liderlik davranışı işletme çalışanlarının performansları ve aidiyet duygusu hissetmeleri açısından önemli olmasına karşın liderlik davranış türlerinin özellikle hizmet sektörü çalışanları üzerinde ne gibi sonuçlar doğurabileceği konusunda yapılan çok boyutlu çalışmalara fazla rastlanılamamaktadır. Konu ile ilgili yapılan çalışmaların azınlıkta kalan kısmı seyahat acenteleri, diğer turizm alanları üzerine olurken büyük bir çoğunluğu otel işletmeleri ve çalışan personel üzerinedir.

İşletmelerin sürekliliği açısından liderlik, örgütsel sessizlik, sinizm ve psikolojik iyi oluş değişkenleri arasındaki ilişkinin birlikte ele alınması ile literatüre yeni bir bakış açısı getirebilecektir. Bu varsayımla nicel araştırma yaklaşımıyla kurgulanmış, verilerin soru formu aracılığıyla elde edildiği çalışmada, liderlik davranış türlerinin örgütsel sessizlik, örgütsel sinizm ve psikolojik iyi oluşa etkisinin, Türkiye ve İtalya'daki konaklama işletmeleri açısından değerlendirilmesi çalışmanın ana amacını oluşturmaktadır. Amaç çerçevesinde araştırma 
probleminin çok boyutlu olarak incelenmesi hedeflenmektedir. $\mathrm{Bu}$ nedenle araştırmanın kavramsal temellerinin oluşturulması aşağıdaki bölümde birlikte incelenecektir.

\section{LİDERLIK, ÖRGÜTSEL SESSİZLIK, ÖRGÜTSEL SİNIZM VE PSIKOLOJIKK İYİ OLUŞ KAVRAMLARININ İLIŞKISII}

21. yüzyıl itibariyle toplum yapısını oluşturan örgütler, teknoloji ve iletişim alanlarındaki hızlı gelişmelere paralel olarak yaşanan yoğun rekabet ortamında, ilgili pazarda söz sahibi olma aşamasına gelebilmek ve bir adım dahi olsa öne geçebilmek için en önemli kaynağının insan olduğunu anlamıştır. Bu gelişme ile birlikte insanları peşinden sürükleyecek ve örgütte motivasyon, bağlılık, etkin verimlilik sağlayabilecek (Bakan ve Büyükbeşe, 2010; Aksu, 2012) işletmenin belirlediği planlarda işletme yönetimi ve iş gücü arasında katalizör görevi üstlenecek (Avey vd., 2008: 48; Ertürk, 2013:173; Sığrı ve Gürbüz, 2014) liderlere gereksinim duyulmaktadır.

Genel anlamda bakıldığında bütün lider ve liderlik tanımlamalarının anahtar sözcükleri amaç, hitap edilen grup üyeleri ve etkileme sözcükleridir (Sı̆̆rı ve Gürbüz, 2014:376). Bütün sözcüklerin ayrı bir öneme sahip olmasının yanında "etkileme" sözcügüüün önemi oldukça fazladır. Nasıl ki fizikte cisimleri harekete geçirmek için güç kullanmak gerekli ve önemli ise, işletme içinde çalışan bireyi harekete geçirmek için de lider tarafından kullanılan güç gereklidir. Fakat burada önemli olan gücün ne derecede ve nasıl olduğudur. Çünkü güç çalışanlar tarafından olumsuz olarak algılandığı takdirde olumsuz davranışlar yaratabilir. Başka bir deyiş ile çalışanların davranışları açısından merkezi rol oynayan liderlerin, gelecekteki davranışlara da yön vermesi (Harms vd., 2017:185) olumsuz davranışlar belirdiğinde de söz konusudur (Stanley vd., 2005).

Turizm sektörü ile ilgili çalışmalar incelendiğinde etkileşimci ve dönüşümcü liderlik tarzları ile personelin işten ayrılma niyeti (Baltacı vd., 2014; Tanrıverdi vd., 2016; Ariyabuddhipshongs ve Kahn, 2017; tükenmişlik düzeyleri ve çatışma yönetimi (Güzel ve Akgündüz, 2011; Bakhtawari vd., 2016), örgütsel bağlllık (Morçin ve Bilgin, 2014; Dlamini vd., 2017; Luo vd., 2017) Örgütsel sessizlik (Erol ve Köroğlu, 2013; K1lıç vd., 2014; Çatır ve Ünlüönen, 2015) iş tatmini (Rothfelder vd., 2012; Spitzbart, 2013; Baltacı vd., 2014; Rachmawati, 2015; Ohunakin vd., 2016) arasındaki ilişkiye yönelik çalışmaların yapıldığı görülmektedir.

İşletme için işlevsel olamayan davranış kalıpları örgütsel yapılanmanın önündeki önemli bir engel olarak görülürken, kaynağı liderlik temelli konular özellikle araştırılması gereken bir durumdur. İşlevsel olmayan davranışların birçoğu arasında göze çarpan örgütsel sessizlik, çalışanların işle ilgili konular ve sorunlar hakkındaki bilgilerini, görüşlerini ve kaygılarını bilinçli olarak yönetimle paylaşmamaları, kendilerine saklamaları olarak ifade edilir. Özellikle yöneticilerin, çalışanlardan gelen katkılara, eleştirilere ve önerilere olumsuz yaklaşması, çalışanların, zamanla sessiz kalmayı tercih edecek bir duruma gelmesine neden olabilmektedir (Piderit ve Ashford, 2003; Özdemir ve Uğur, 2013).

H1: Etkileşimci liderlik davranışı, konaklama işletmelerinde çalışan personelin örgütsel sessizlik davranışı üzerinde etkilidir

H2: Dönüşümcü liderlik davranışı, konaklama işletmelerinde çalışan personelin örgütsel sessizlik davranışı üzerinde etkilidir

Litaretürde sessizliğin, çalışanın bulunduğu örgüte ilişkin olumsuz davranış, duygu ve düşünceler şeklinde görülen tutumu olarak tanımlanan sinizmi meydana getirebileceği (James, 2005; Polat ve Meydan, 2010) sinizmin ise, bireyde yaratılan olumlu benlik algisını, etrafında bulunan diğer bireylerle var olan iyi ilişkilerini, çevresel hâkimiyetini, yaşamın anlamını ve kendini kabul ettirebilmeden dolayı yaşanan olumlu duygularını temsil eden psikolojik iyi oluş 
durumuna da olumsuz etki edebileceğini (Ryff, 1989; Keyes vd., 2002) ifade eden araştırmalara ulaşılmıştır.

H3: İşletme içinde var olan örgütsel sessizlik yine işletme içinde var olan örgütsel sinizm davranışı üzerinde etkilidir.

H4: İşletme içinde var olan örgütsel sinizm, konaklama işletmelerinde çalışan personelin psikolojik iyi oluş davranışı üzerinde etkilidir.

Bir örgüt içinde artık günümüzde sık sık karşılaşılan kavramlardan olan örgütsel sessizlik, örgütsel sinizm ve psikolojik iyi oluş hali hem örgüt hem de birey açısından önemli olan kavramlardır. Literatür incelendiğinde değişkenler ile ilgili tek başına birçok farklı çalışmaya rastlanılmasına rağmen değişkenler arasındaki ilişkiyi inceleyen bütüncül bir çalışmaya Türkçe ve yabancı literatürde rastlanılamaması çalışmanın önemini arttırmaktadır. Kavramların en önemli özelliği ise birbirinin devamı niteliğinde ve birbirlerinin tetikleyicileri olabilme olasılıklarıdır. Bir örgütte görev alan bireyde ortaya çıkan bu davranış/tutumlardan biri, bir diğerinin habercisi olabildiği gibi bunların bireyde görülmesi örgüt açısından olumsuz sonuçlar doğurabilir. Sonuç olarak, bu davranış ve tutumları bir örgütte minimize edecek olanın iş görene karşı tutum ve davranış geliştiren liderler olduğu varsayılmaktadır.

\section{YÖNTEM}

Araştırma; etkileşimci ve dönüşümcü liderliğin örgütsel sessizlik, örgütsel sinizm ve psikolojik iyi oluş etkisi üzerine odaklanarak Türkiye'den Antalya Bölgesini, İtalya'da ise Amalfi Coast bölgesinde faaliyet gösteren konaklama işletmeleri çalışanlarını araştırma konusu yapmıştır. $\mathrm{Bu}$ bölgelerin seçim nedeni ise turizm sektörüne uygun şekilde benzer özellikler taşıyan turistik destinasyon olmalarıdır. Her iki ülkede bulunan iki bölgenin de yüksek bir oranda turist çekiciliğe sahip olması en belirgin özellikleridir.

\section{Araştırma Modeli}

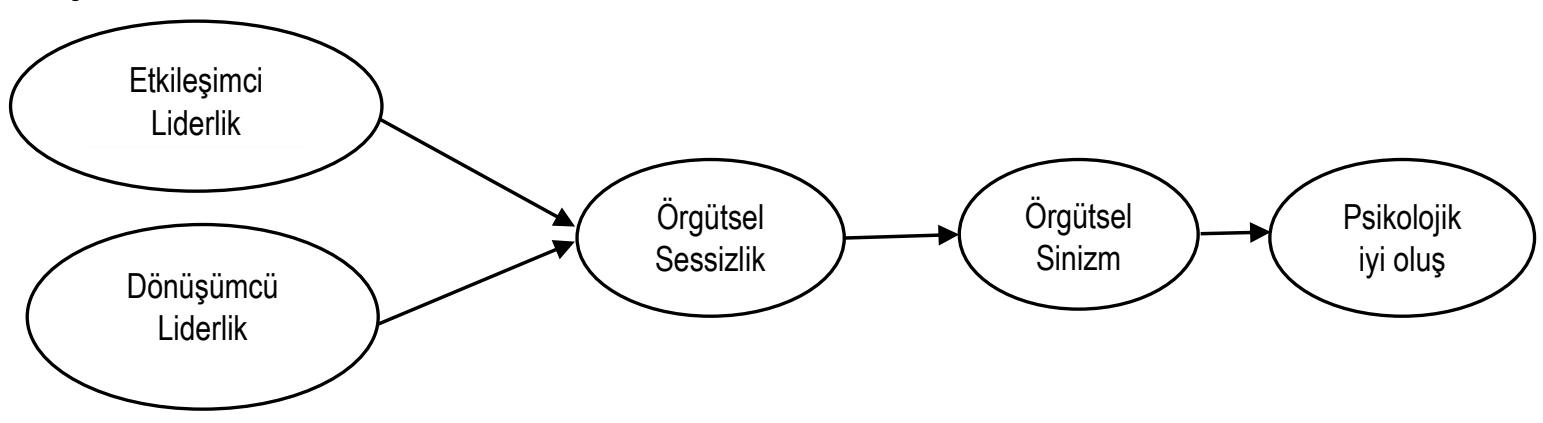

Şekil 1: Varsayılan Araştırma Modeli

\section{Araştırma Evren ve Örneklem}

Çalışmanın kültürlerarası bir çalışma olmasından yola çıkılarak, araştırmanın evrenini turizm işletme belgesine sahip Antalya (Türkiye) ve Amalfi Coast (İtalya) bölgesinde bulunan dört-beş yıldızlı otel çalışanları oluşturmaktadır. Araştırmada zaman ve maliyet faktöründen dolayı evren üzerinden örneklem alma yoluna gidilmiştir. 
Çalışma Amalfi Coast (İtalya) merkezli turizm destinasyon merkezlerinden olan Sorento, Capri, Salerno, Positano'da bulunan konaklama işletmeleri ile Antalya merkez, Kemer, Belek, Side ve Alanya'daki konaklama işletmelerinde gerçekleştirilmiştir. Antalya genelinde 718 çalışan personel örneklem olarak belirlenirken bu sayı Amalfi Coastta 357 personelle sınırlı kalmıştır. İşletmelere dağıtılan 1250 soru formundan 1075 tanesi analize uygun bulunmuştur. Bu katılım sayısı bir kısıt olarak alınırken, araştırma sonuçları ancak uygulanılan örneklemi temsil yeteneğine sahiptir.

\section{Verilerin Toplanması ve Ölçekler}

Araştırmada verilerin toplanmasında anket formundan yararlanılmıştır. Soru formu 5 bölümden oluşmakta olup; birinci bölüm demografik ve katılımcıların iş hayatına ilişkin genel bilgileri içermektedir. İkinci bölüm liderlik, üçüncü bölüm örgütsel sessizlik, dördüncü bölüm sinizm ve beşinci bölüm psikolojik iyi oluş ile ilgili önermelerden oluşmaktadır. İkinci, üçüncü, dördüncü ve beşinci bölümdeki önermelere katılım derecesi Likert tipinde sorgulanmış olup, bireyin önermelere katılım derecesini ölçmektedir.

Bu araştırmada, liderlik davranışını belirlemeye yönelik olarak Bass ve Avolio (1995) tarafından geliştirilmiş “Çoklu Faktör Liderlik Ölçeği (Multifactor Leadership Questionnaire -MLQ)" 36 önermeden oluşan 9 boyutlu bir ölçek olarak gözden geçirilerek kullanılmıştır.

Örgütsel sessizlikle ölçeğinde ise, 2007 yılında Çakıcı \&Çakıcı tarafında yazına dayalı geliştirilen soru formundan yararlanılmıştır. Ölçek, 28 sorudan oluşan 5 boyutlu bir ölçektir.

Örgütsel Sinizm Ölçeği (ÖsÖ) Brandes, Dharwadkar ve Dean (1999) tarafından geliştirilmiştir 13 soruluk tek boyutlu bir ölçek iken, Psikolojik iyi oluş ölçeği, Diener, Wirtz, Biswas-Diener, Tov, Kim-Prieto, Choi ve Oishi'nin (2010) New Measures of Well-Being adlı çalışmasından uyarlanmış olup 10 sorulu tek boyutlu bir ölçektir.

\section{Araştırmada Kullanılan Ölçeklerin Güvenilirlik Analizi}

Otuz altı ifadeden oluşan liderlik, yirmi sekiz ifadeden oluşan örgütsel sessizlik, on üç ifadeden oluşan örgütsel sinizm ve on ifadeden oluşan psikolojik iyi oluş ölçeklerinin güvenilirliklerini ölçmek için alfa katsayısı kullanılmıştır.

Tablo 1: Güvenilirlik Analizi Sonuçları

\begin{tabular}{ll}
\hline Ölçek & Alpha Katsayısı $(\boldsymbol{\alpha}=)$ \\
\hline Etkileşimci Liderlik & 0.866 \\
Dönüşümcü Liderlik & 0.960 \\
Örgütsel Sessizlik & 0.973 \\
Örgütsel Sinizm & 0.961 \\
Psikolojik İyi Oluş & 0.932 \\
\hline
\end{tabular}

Alpha katsayılarına bakıldığında, dönüşümcü liderlik, örgütsel sessizlik, örgütsel sinizm ve psikolojik iyi oluş ölçeklerinin güvenilirliğinin yüksek derecede olduğu belirlenirken, etkileşimci liderlik ölçeğinin ise yüksek derecede güvenilir olduğu gözlemlenmiştir (Özdamar, 1999; Can, 2014:47). 


\section{Ölçeklerin Geçerliliklerine İlişkin Analizler}

Ölçeklerin yapı geçerliliğini ölçmek ve boyutların kendi aralarında toplanıp toplanmadığını belirlemek amacıyla açımlayıcı faktör analizi uygulanmıştır.

\section{Etkileşimci Liderlik Ölçeği}

1075 kişiden oluşan örneklemin, büyüklük açısından faktör analizi için veri yapısının uygunluğunu değerlendirmek amacıyla, KMO (Kaiser Meyer Olkin) değeri hesaplanmıştır. Bu değerin 0,873 olması nedeniyle veri yapısının faktör analizi yapılabilmesi için iyi derecede yeterli olduğu değerlendirilmesi yapılabilir. (Çokluk vd., 2010: 177).

Tablo 2: Etkileşimci Liderlik Ölçeği KMO ve Bartlett Testi Sonuç Tablosu

\begin{tabular}{ll}
\hline Kaiser-Meyer-Olkin & 0.873 \\
\hline Bartlett Testi & 9373,448 \\
df & 120 \\
Sig. &, 000 \\
\hline
\end{tabular}

Barlett testi sonuçları incelendiğinde ise elde edilen ki-kare $\left(\chi^{2}(120)=9373,448 ; p<.01\right)$ değerinin 0,01 düzeyinde manidar olduğu görülmüş olup verilerin çok değişkenli normal dağlımdan geldiği kabul edilmiştir. Böylece faktör analizinin sonuçlarının değerlendirilmesine devam edilebileceğine karar verilmiştir. Yapılan analiz sonucunda, maddelerin varyanslarının genellikle yüksek olduğu tespit edilmiştir. Açıklanan toplam varyans analizi sonucunda, faktör analizi için 4 faktör önerilmiştir. Analizde 4 faktörün varyansa yaptığ1 katkının \%70,848 olduğu görülmüştür. Bu çerçevede tanımlanan bir faktörün toplam varyansa yaptığı katkının yeterli olduğu söylenebilir.

Etkileşimci liderlik ölçeğinin faktör desenini ortaya koymak amacıyla faktörleştirme yöntemi olarak temek bileşenler analizi; döndürme yöntemi olarak da dik döndürme yöntemlerinden döndürme işlemi (varimax-maximum değişkenlik ) seçilmiştir. Maddeler binişiklik ve faktör yük değerlerinin kabul düzeyini karşılayıp karşılamaması açısından değerlendirilmiştir. Değerlendirme sonucunda maddeler toplam varyansın da önerdiği gibi 4 ayrı boyut altında toplanmış olup yük değerleri kabul noktası 0,32 olarak kabul edildiğinde bu kabul düzeyini karşılamayan bir ifade ile karşılaşılmamıştır. Bu faktör analizinde madde çıkarmama kararı verilmiştir.

\section{Dönüşümcü Liderlik Ölçeği}

1078 kişiden oluşan örneklemin, büyüklük açısından faktör analizi için veri yapısının uygunluğunu değerlendirmek amacıyla, KMO (Kaiser Meyer Olkin) değeri hesaplanmıştır. Bu değerin 0,965 olması nedeniyle veri yapısının faktör analizi yapılabilmesi için mükemmel derecede yeterli olduğu değerlendirilmesi yapılabilir. (Çokluk vd., 2010: 177). 
Tablo 3: Dönüşümcü Liderlik Ölçeği KMO ve Bartlett Testi Sonuç Tablosu

\begin{tabular}{ll}
\hline Kaiser-Meyer-Olkin & 0.965 \\
\hline Bartlett Testi & 16395,639 \\
df & 190 \\
Sig. &, 000 \\
\hline
\end{tabular}

Barlett testi sonuçları incelendiğinde ise elde edilen ki-kare $\left(\chi^{2}(190)=16395,639 ; p<.01\right)$ değerinin 0,01 düzeyinde manidar olduğu görülmüş olup verilerin çok değişkenli normal dağlımdan geldiği kabul edilmiştir. Böylece faktör analizinin sonuçlarının değerlendirilmesine devam edilebileceğine karar verilmiştir. Yapılan analiz sonucunda, maddelerin varyanslarının genellikle yüksek olduğu tespit edilmiştir. Açıklanan toplam varyans analizi sonucunda, faktör analizi için 5 faktör önerilmiştir. Analizde 5 faktörün varyansa yaptığı katkının \%75,652 olduğu görülmüştür. Bu çerçevede tanımlanan bir faktörün toplam varyansa yaptığı katkının yeterli olduğu söylenebilir.

Dönüşümcü liderlik ölçeğinin faktör desenini ortaya koymak amacıyla faktörleştirme yöntemi olarak temek bileşenler analizi; döndürme yöntemi olarak da dik döndürme yöntemlerinden döndürme işlemi (varimax-maximum değişkenlik) seçilmiştir. Maddeler binişiklik ve faktör yük değerlerinin kabul düzeyini karşılayıp karşılamaması açısından değerlendirilmiştir. Değerlendirme sonucunda maddeler toplam varyansın da önerdiği gibi 5 ayrı boyut altında toplanmış olup yük değerleri kabul noktası 0,32 olarak kabul edildiğinde bu kabul düzeyini karşılamayan bir ifade ile karşılaşılmamıştır. Bu faktör analizinde madde çıkarmama kararı verilmiştir.

\section{Örgütsel Sessizlik Ölçeği}

31075 kişiden oluşan örneklemin, büyüklük açısından faktör analizi için veri yapısının uygunluğunu değerlendirmek amacıyla, KMO (Kaiser Meyer Olkin) değeri hesaplanmıştır. Bu değerin 0,973 olması nedeniyle veri yapısının faktör analizi yapılabilmesi için mükemmel derecede yeterli olduğu değerlendirilmesi yapılabilir(Çokluk vd., 2010: 177).

Tablo 4: Örgütsel Sessizlik Ölçeği KMO ve Bartlett Testi Sonuç Tablosu

\begin{tabular}{ll}
\hline Kaiser-Meyer-Olkin & 0.973 \\
\hline Bartlett Testi & 29062,831 \\
df & 378 \\
Sig. &, 000 \\
\hline
\end{tabular}

Barlett testi sonuçları incelendiğinde ise elde edilen ki-kare $\left(\chi^{2}(378)\right.$ 29062,831;p<.01) değerinin 0,01 düzeyinde manidar olduğu görülmüş olup verilerin çok değişkenli normal dağlımdan geldiği kabul edilmiştir. Böylece faktör analizinin sonuçlarının değerlendirilmesine devam edilebileceğine karar verilmiştir. Yapılan analiz sonucunda, maddelerin varyanslarının genellikle yüksek olduğu tespit edilmiştir. Açıklanan toplam varyans analizi sonucunda, faktör analizi için 5 faktör önerilmiştir. Analizde 5 faktörün varyansa yaptığı katkının $\% 76,601$ olduğu görülmüştür. 
Örgütsel Sessizlik ölçeğinin olarak temek bileşenler analizi; döndürme yöntemi olarak da dik döndürme yöntemlerinden döndürme işlemi (varimax-maximum değişkenlik) seçilmiştir. Maddeler binişiklik ve faktör yük değerlerinin kabul düzeyini karşılayıp karşılamaması açısından değerlendirilmiştir. 10, 11 ve 12 . Maddelerin 1'den fazla faktörde kabul düzeyinden (0.32) yüksek yük değeri vermesi ve 2 faktörde de sahip olduğu yük değerleri asındaki farkın 0,1'den küçük olduğu görülmüştür. Bununla birlikte 1 ve 2 . maddeler kendi grupları arasında yer almamıştır. Bu nedenle 1, 2, 10, 11 ve 12 maddelerin ölçekten çıkarılmasına karar verilmiştir.

Tablo 5: Maddeler Çıkartılmıș Döndürülmüş Bileşenler Matrixi Tablosu

\begin{tabular}{|c|c|c|c|c|c|}
\hline & \multicolumn{5}{|c|}{ Component } \\
\hline & 1 & 2 & 3 & 4 & 5 \\
\hline Ö5: & 794 & 217 & 270 & 186 & 106 \\
\hline Ö6: & 759 & 262 & 313 & 146 & 173 \\
\hline Ö3: & 745 & 130 & 269 & 165 & 237 \\
\hline Ö7: & 738 & 233 & ,349 & 181 & 126 \\
\hline Ö4: & 737 & 188 & 182 & 168 & 142 \\
\hline Ö8: & 729 & 174 & 369 & 173 & 160 \\
\hline Ö9: & ,645 & 170 & ,409 & 160 & 257 \\
\hline Ö23: & 216 & 802 & 216 & 298 & 175 \\
\hline Ö24: & ,242 & 791 & 202 & 266 & 161 \\
\hline Ö25: & 218 & 770 & 221 & 243 & 256 \\
\hline Ö22: & ,228 & 766 & 193 & 308 & 167 \\
\hline Ö15: & ,407 & 233 & ,751 & 163 & 194 \\
\hline Ö16: & ,394 & 242 & 736 & 186 & 190 \\
\hline Ö14: & ,406 & 234 & ,711 & 193 & 192 \\
\hline Ö17: & ,394 & 148 & 696 & 230 & 162 \\
\hline Ö13: & ,468 & 294 & ,652 & 153 & 140 \\
\hline Ö19: & 161 & 218 & 119 & 815 & \\
\hline Ö18: & 130 & 153 & 158 & ,803 & 128 \\
\hline Ö20: & 196 & 284 & 190 & 784 & 101 \\
\hline Ö21: & ,250 & 406 & 147 & 667 & 157 \\
\hline Ö27: & ,330 & 349 & 310 & 221 & 711 \\
\hline Ö28: & 397 & 367 & 269 & 207 & 659 \\
\hline Ö26: & ,344 & ,468 & 298 & 206 & 609 \\
\hline
\end{tabular}

Analiz dışı kalmış olan maddeler sonucu döndürülmüş bileşenler matrisi incelendiğinde, maddelerin teorik olarak tanımlanan yapılar altında yer aldığı belirlenmiştir. Bu noktada 4 faktörlü yapının varyansa yaptığı katkıyı belirlemek amacıyla açıklanan toplam varyans tablosu incelenmiştir. 1, 2, 10, 11 ve 12. maddelerinin analiz dışı bırakılması ile 5 faktörün varyansı açıklama oranının \%78,994 olduğu görülmüştür. Bu çerçevede tanımlanan bir faktörün toplam varyansa yaptığı katkının yeterli olduğu söylenebilir.

\section{Örgütsel Sinizm Ölçeği}

1078 kişiden oluşan örneklemin, büyüklük açısından faktör analizi için veri yapısının uygunluğunu değerlendirmek amacıyla, KMO (Kaiser Meyer Olkin) değeri hesaplanmıştır. Bu 
değerin 0,952 olması nedeniyle veri yapısının faktör analizi yapılabilmesi için mükemmel derecede yeterli olduğu değerlendirilmesi yapılabilir(Çokluk vd., 2010: 177).

Tablo 6: Örgütsel Sinizm Ölçeği KMO ve Bartlett Testi Sonuç Tablosu

\begin{tabular}{ll}
\hline Kaiser-Meyer-Olkin & 0.952 \\
\hline Bartlett Testi & 14366,029 \\
df & 78 \\
Sig. &, 000 \\
\hline
\end{tabular}

Barlett testi sonuçları incelendiğinde ise elde edilen ki-kare ( $\left.\chi^{2}(78) 14366,029 ; p<.01\right)$ değerinin 0,01 düzeyinde manidar olduğu görülmüş olup verilerin çok değişkenli normal dağılımdan geldiği kabul edilmiştir. Böylece faktör analizinin sonuçlarının değerlendirilmesine devam edilebileceğine karar verilmiştir.

Analizde faktör sayısının 1 olarak belirlenmesi nedeniyle, faktör yük değerleri arasındaki binişiklik problemi göz önünde bulundurulmamıştır. Tek faktörlü desenlerde açıklanan varyansın \%30 ve daha fazlası yeterli görülürken, tanımlanan faktörün, toplam varyansa yaptığ 1 katkının $(\% 68,033)$ yeterli olduğu görülmektedir. Maddeler faktör yük değerleri açısından incelendiğinde ve yük değerleri kabul noktası 0,32 olarak kabul edildiğinde bu kabul düzeyini karşılamayan bir ifade ile karşılaşılmamıştır. Bu faktör analizinde madde çıarmama kararı verilmiştir.

\section{Psikolojik İyi Oluş Ölçeği}

1078 kişiden oluşan örneklemin, büyüklük açısından faktör analizi için veri yapısının uygunluğunu değerlendirmek amacıyla, KMO (Kaiser Meyer Olkin) değeri hesaplanmıştır. Bu değerin 0,937 olması nedeniyle veri yapısının faktör analizi yapılabilmesi için mükemmel derecede yeterli olduğu değerlendirilmesi yapılabilir(Çokluk vd., 2010: 177).

Tablo 7: Psikolojik İyi Oluş Ölçeği KMO ve Bartlett Testi Sonuç Tablosu

\begin{tabular}{ll}
\hline Kaiser-Meyer-Olkin & 0.937 \\
\hline Bartlett Testi & 7341,089 \\
df & 45 \\
Sig. &, 000 \\
\hline
\end{tabular}

Barlett testi sonuçları incelendiğinde ise elde edilen ki-kare $\left(\chi^{2}(45) 7341,089 ; p<.01\right)$ değerinin 0,01 düzeyinde manidar olduğu görülmüş olup verilerin çok değişkenli normal dağılımdan geldiği kabul edilmiştir. Böylece faktör analizinin sonuçlarının değerlendirilmesine devam edilebileceğine karar verilmiştir.

Analizde faktör sayısının 1 olarak belirlenmesi nedeniyle, faktör yük değerleri arasındaki binişiklik problemi göz önünde bulundurulmamıştır. Tek faktörlü desenlerde açıklanan varyansın \%30 ve daha fazlası yeterli görülürken, tanımlanan faktörün, toplam varyansa yaptığ1 katkının $(\% 62,298)$ yeterli olduğu görülmektedir. Maddeler faktör yük değerleri açısından incelendiğinde ve yük değerleri kabul noktası 0,32 olarak kabul edildiğinde bu kabul düzeyini 
karşılamayan bir ifade ile karşılaşılmamıştır. Bu faktör analizinde madde çıkarmama kararı verilmiştir.

\section{Verilerin Analizi}

Araştırmada elde edilen verilerin analizinde veri yapısına göre farklı istatistiksel yöntemler kullanılmıştır. Demografik ve kişisel bilgilerin analizinde tanımlayıcı istatistikler (yüzde, frekans, ortalama, medyan ve standart sapma) kullanılırken, değişkenler arasındaki ilişkinin varlığı ve yönünün belirlenmesinde ilişkisel testlerden korelasyon katsayısı, değişkenlerin birbirleri ile aralarında olan etki düzeyini belirlemek için ise basit doğrusal regresyon analizinden yararlanılmıştır.

\section{BULGULAR}

Araştırmanın bu bölümünde İtalya ve Türkiye' de farklı destinasyon merkezlerinde bulunan 4 ve 5 yıldızlı konaklama işletmelerinde görev yapan personele uygulanan Etkileşimci ve Dönüşümcü Liderliğin, Örgütsel Sessizlik, Örgütsel Sinizm ve Psikolojik İyi Oluşa Etkisinin belirlenmesi ile ilgili sunulan anketlerin neticesinde elde edilen verilere ilişkin bulgulara ve yorumlara yer verilmiştir.

\section{Araştırmaya Katılan Konaklama İşletmeleri Personelinin (Türkiye-İtalya) Bireysel Özelliklerine İlişkin Bulgular}

Tablo 8. Araştırmaya Katılan Türk ve İtalyan Personelin Demografik Özelliklerine İlişkin Bilgileri

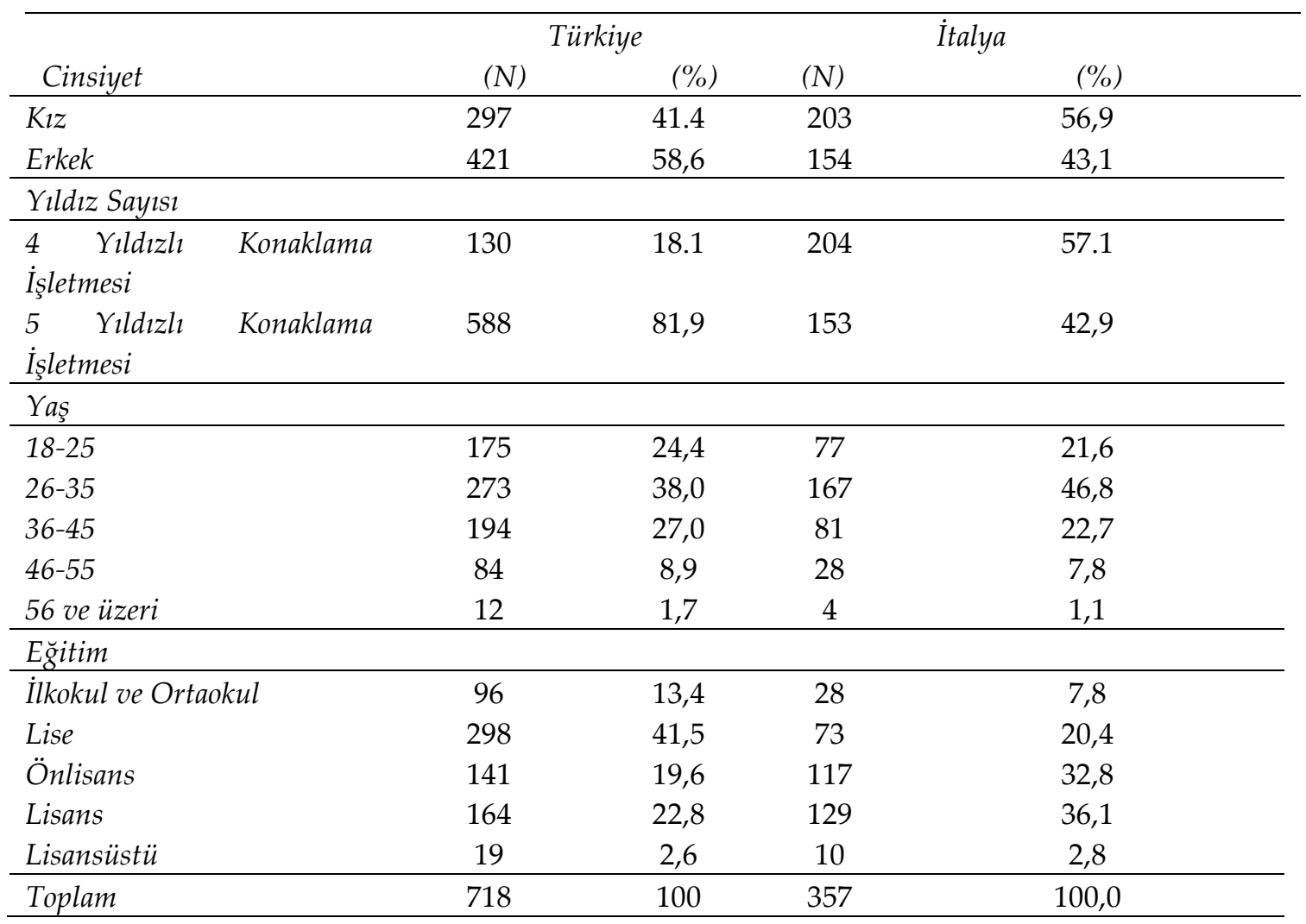


Çalışan personelin demografik özelliklerine ilişkin bilgiler tablo 8' de gösterilmiştir. Toplamda 718 çalışan personelden oluşan bu bulgulara göre çalışanların \%58,6's1 erkek \%41,4'ü ise bayandır. Analize tabi tutulan personelin çalıştığı konaklama işletmelerinin büyük çoğunluğu $\% 81,9^{\prime}$ u beş yıldızlı konaklama işletmesi kapasitesine sahiptir. Tablo $8^{\prime}$ de verilen yaşla ilgili verilere bakılarak çalışan personelin çoğunluğunun (\%62,4'ü 18-35 yaş aralığında) genç olduğu yorumu yapılabilir. Araştırmaya katılan personelin eğitim durumları incelendiğinde, $\% 41,5$ 'inin lise, \%19,6'sının ön lisans ve \%22,8'inin lisans eğitime sahip olduğu görülmektedir.

İtalya'da bulunan konaklama işletmelerinde çalışan personelin yaşla ilgili verilerine bakılarak çalışan personelin çoğunluğunun Türkiye'de ki çalışan yaş aralığı ile benzerlik göstererek genç olduğu görülmektedir.

Araştırmaya Katılan Konaklama İşletmeleri Personelinin (Türkiye-İtalya) Etkileşimci, Dönüşümcü Liderlik, Örgütsel Sessizlik, Örgütsel Sinizm ve Psikolojik İyi Oluş Algılamaları Arasındaki İlişkinin Değerlendirilmesi

Tablo 9: Araştırmaya Katılan Konaklama İşletmeleri Personelinin (Türkiye-İtalya) Etkileşimci, Dönüşümcü Liderlik, Örgütsel Sessizlik, Örgütsel Sinizm ve Psikolojik İyi Oluş Algılamaları Arasındaki İlişkinin Değerlendirilmesine Yönelik Korelasyon Tablosu

\begin{tabular}{|c|c|c|c|c|c|}
\hline & $\begin{array}{l}\text { Etkileşimci } \\
\text { Liderlik }\end{array}$ & $\begin{array}{l}\text { Dönüşümcü } \\
\text { Liderlik }\end{array}$ & $\begin{array}{l}\text { Örgütsel } \\
\text { Sessizlik }\end{array}$ & Sinizm & $\begin{array}{l}\text { Psikolojik } \\
\text { iyi oluş }\end{array}$ \\
\hline $\begin{array}{l}\text { Etkileşimci } \\
\text { Liderlik }\end{array}$ & 1 & & & & \\
\hline $\begin{array}{l}\text { Dönüşümcü } \\
\text { Liderlik }\end{array}$ &, $530^{* *}$ & 1 & & & \\
\hline Örgütsel Sessizlik &, $330 * *$ & $157^{* *}$ & 1 & & \\
\hline Sinizm & $325^{* *}$ & ,016 &, $764^{* *}$ & 1 & \\
\hline Psikolojik iyi oluş &,$- 308^{* *}$ &, $422^{* *}$ &,- 001 &,- 096 & 1 \\
\hline
\end{tabular}

** $\mathrm{p}<0,01$ anlamlılık düzeyinde (iki yönlü)

* $\mathrm{p}<0,05$ anlamlılık düzeyinde (iki yönlü)

Etkileşimci liderlik ile örgütsel sessizlik arasındaki korelasyon ilişkisine bakıldığında $p<0,01$ anlamlılık düzeyinde $\left(\mathrm{r}=0,330^{* *}\right)$ doğrusal yönlü zayıf bir ilişkinin varlığı kendini gösterirken, dönüşümcü liderlik ile örgütsel sessizlik değişkenleri arasında $\left(\mathrm{r}=0,157^{* *}\right)$ doğrusal yönlü zayıf bir ilişkinin varlığı kendisini göstermektedir. İki liderlik arasındaki ilişki bakıldığında $p<0,01$ anlamlllık düzeyinde $\left(\mathrm{r}=-0,530^{* *}\right)$ ve ters yönlü orta seviyede bir ilişki olduğu görülmektedir. Örgütsel sessizlik ile diğer değişken olan örgütsel sinizm arasında ki korelasyona bakıldığında ise $\mathrm{p}<0,01$ anlamlılık düzeyinde $\left(r=0,764^{* *}\right)$ orta seviyede doğrusal yönlü bir ilişkinin varlığ kendisini göstermektedir. Bağımsız değişken olan örgütsel sinizm ile bağımlı değişken olarak adlandırılan psikolojik iyi oluş arasındaki ilişki incelendiğinde ise ortaya çıkan sonuç, $p<0,01$ anlamlılık düzeyinde $\left(\mathrm{r}=-0,096^{* *}\right)$ ve ters yönlü zayıf bir ilişkinin kendini gösterdiğidir. Etkileşimci liderlik ile örgütsel sinizm arasında $\mathrm{p}<0,01$ anlamlllık düzeyinde $\left(r=0,325^{* *}\right)$ ve doğrusal yönlü orta seviyede bir ilişki mevcuttur. Son olarak psikolojik iyi oluş ile liderlikler arasında ki korelasyon ilişkisi sorgulandığında dönüşümcü liderlik ile psikolojik iyi oluş arasında $\mathrm{p}<0,01$ anlamlılık düzeyinde $\left(\mathrm{r}=0,422^{* *}\right)$ doğrusal yönlü orta seviyede bir ilişki olduğu belirtilirken, etkileşimci liderlik ile psikolojik iyi oluş arasında $\mathrm{p}<0,01$ anlamlılık düzeyinde ( $\mathrm{r}=-$ $0,308^{* *}$ ) ters yönlü orta seviyede bir ilişkinin var olduğu belirtilmektedir. 
Araştırmada etkileşimci ve dönüşümcü liderliğin örgütsel sessizlik, örgütsel sinizm ve psikolojik iyi oluş arasındaki ilişkiyi belirlemek için korelasyon değerleri bulunmuştur. Korelasyon katsayıları Tablo 10'da görülmektedir.

Araştırmaya Katılan Konaklama İşletmeleri Personelinin (Türkiye-İtalya) Etkileşimci, Dönüşümcü Liderlik, Örgütsel Sessizlik, Örgütsel Sinizm ve Psikolojik İyi Oluş Algılamaları Arasındaki İlişkinin Değerlendirilmesi

Tablo 10: Ölçekler İlişkin Korelasyon Analizi Sonuçları

\begin{tabular}{|c|c|c|c|c|c|}
\hline & $\begin{array}{c}\text { Etkileşimci } \\
\text { Liderlik }\end{array}$ & $\begin{array}{l}\text { Dönüşümcü } \\
\text { Liderlik }\end{array}$ & $\begin{array}{l}\text { Örgütsel } \\
\text { Sessizlik }\end{array}$ & $\begin{array}{c}\text { Örgütsel } \\
\text { Sinizm }\end{array}$ & $\begin{array}{l}\text { Psikolojik İyi } \\
\text { Oluş }\end{array}$ \\
\hline Etkileşimci & 1 & & $330^{* *}$ & $325^{* *}$ & \\
\hline Liderlik & & & & & \\
\hline $\begin{array}{l}\text { Dönüşümcü } \\
\text { Liderlik }\end{array}$ &,$- 530^{* *}$ & 1 & $157^{* *}$ & & \\
\hline $\begin{array}{l}\text { Liderlik } \\
\text { Örgütsel } \\
\text { Sessizlik }\end{array}$ & & & 1 &, $764^{* *}$ & \\
\hline $\begin{array}{l}\text { Örgütsel Sinizm } \\
\text { Psikolojik İyi } \\
\text { Oluş }\end{array}$ &,$- 308^{* *}$ &, $422^{* *}$ & & 1 & $\begin{array}{c}-, 096^{* *} \\
1\end{array}$ \\
\hline
\end{tabular}

** $\mathrm{p}<0,01$ anlamlılık düzeyinde (iki yönlü)

* $\mathrm{p}<0,05$ anlamlılık düzeyinde (iki yönlü)

Etkileşimci liderlik ile örgütsel sessizlik arasındaki korelasyon ilişkisine bakıldığında $p<0,01$ anlamlılık düzeyinde $\left(\mathrm{r}=330^{* *}\right)$ doğrusal yönlü zayıf bir ilişkinin varlığı kendini gösterirken, dönüşümcü liderlik ile örgütsel sessizlik değişkenleri arasında $\left(r=157^{* *}\right)$ doğrusal yönlü zayıf bir ilişkinin varlığı kendisini göstermektedir. İki liderlik arasındaki ilişki bakıldığında $p<0,01$ anlamlılık düzeyinde $\left(\mathrm{r}=-530^{* *}\right)$ ve ters yönlü orta seviyede bir ilişki olduğu görülmektedir. Örgütsel sessizlik ile diğer değişken olan örgütsel sinizm arasında ki korelasyona bakıldığında ise $\mathrm{p}<0,01$ anlamlılık düzeyinde $\left(\mathrm{r}=764^{* *}\right)$ orta seviyede doğrusal yönlü bir ilişkinin varlığ kendisini göstermektedir. Bağımsız değişken olan örgütsel sinizm ile bağımlı değişken olarak adlandırılan psikolojik iyi oluş arasındaki ilişki incelendiğinde ise ortaya çıan sonuç, $p<0,01$ anlamlılık düzeyinde $\left(\mathrm{r}=-096^{* *}\right)$ ve ters yönlü zayıf bir ilişkinin kendini gösterdiğidir. Etkileşimci liderlik ile örgütsel sinizm arasında $p<0,01$ anlamlılık düzeyinde $\left(r=, 325^{* *}\right)$ ve doğrusal yönlü orta seviyede bir ilişki mevcuttur. Son olarak psikolojik iyi oluş ile liderlikler arasında ki korelasyon ilişkisi sorgulandığında dönüşümcü liderlik ile psikolojik iyi oluş arasında $p<0,01$ anlamlılık düzeyinde $\left(\mathrm{r}=422^{* *}\right)$ doğrusal yönlü orta seviyede bir ilişki olduğu belirtilirken, etkileşimci liderlik ile psikolojik iyi oluş arasında $\mathrm{p}<0,01$ anlamlılık düzeyinde $\left(\mathrm{r}=-, 308^{* *}\right)$ ters yönlü orta seviyede bir ilişkinin var olduğu belirtilmektedir. 


\section{Örgütsel Sessizlik Bağımlı Değişken Olmak Üzere Doğrusal Regresyon Analizi}

Etkileşimci Liderlik Bağımsız Örgütsel Sessizlik Bağımlı Değiş̧ken Olmak Üzere Doğrusal Regresyon Analizi

Tablo 11: Etkileşimci Liderlik İle Örgütsel Sessizlik Arasındaki İlişkinin Derecesini Gösteren R. Değerinin Anlamlılığını Sınayan Varyans (Anova) Analizi

\begin{tabular}{lllllll}
\hline Model & & $\begin{array}{l}\text { Kareler } \\
\text { Toplam }\end{array}$ & Df & $\begin{array}{l}\text { Ort. } \\
\text { Kareler } \\
\text { Değeri }\end{array}$ & F & Sig. \\
\hline 1 & Regresyon & 134.657 & 1 & 134,657 & 131,102 & $000 \mathrm{~b}$ \\
& Artık Değer & 1102,096 & 1073 & 1,027 & & \\
& Toplam & 1236,753 & 1074 & & & \\
\hline
\end{tabular}

a. Bağımlı Değişken = Örgütsel Sessizlik

b. Yordayan $($ sabit $)=$ Etkileşimli Liderlik

Tablodaki $p$ değeri $(p<, 01)$ göz önüne alındığında regresyon modelindeki, bağımsız değişken etkileşimci liderlik ile bağımlı değişken örgütsel sessizlik arasındaki ilişki için hesaplanan değerin $\left(R=0,330^{* *}\right)$ istatistiksel olarak anlamlı olduğu görülmektedir.

Tablo 12: Etkileşimci Liderlik İle Örgütsel Sessizlik Arasındaki İlişkiye Ait Regresyon Katsayıları Tablosu

\begin{tabular}{|c|c|c|c|c|c|}
\hline Model & $\begin{array}{l}\text { Standardize } \\
\text { Edilmemiş } \\
\text { katsayılar } \\
\text { B }\end{array}$ & Std.Hata & $\begin{array}{l}\text { Standardize } \\
\text { Edilmiş } \\
\text { Katsayilar } \\
\text { Beta }\end{array}$ & $\mathrm{T}$ & Sig. \\
\hline 1 (Sabit) & 2,001 & ,114 & & 17,591 & 000 \\
\hline $\begin{array}{l}\text { Etkileşimci } \\
\text { Liderlik }\end{array}$ & ,468 & ,041 & ,330 & 11,450 & 000 \\
\hline
\end{tabular}

Bağımlı Değişken: Örgütsel Sessizlik

Etkileşimci liderliğin, örgütsel sessizliği ne şekilde yordadığını ortaya koymak için yapılan basit doğrusal regresyon analizi sonucunda, etkileşimci liderlik ile örgütsel sessizlik arasında anlamlı ilişki olduğu gözlenmiş ( $R=0,330, R 2=0,109)$, etkileşimci liderliğin örgütsel sessizliğin bir yordayıcısı olduğu görülmüştür $(F(1-1073)=131,102, p<0,01)$. Çalışmada yer verilen liderlik davranış türlerinden olan etkileşimci liderlik örgütsel sessizlikteki değişimin \%10'unu açıklamaktadır. Regresyon denkleminde esas yordayıcı değişkenin katsayısının $(B=0,468)$ anlamlılık testi de etkileşimci liderliğin anlamlı bir yordayıcı olduğunu göstermektedir $(p<0,01)$. Regresyon analizi sonucuna göre, örgütsel sessizliği yordayan regresyon denklemi şu şekildedir: Örgütsel Sessizlik $=(0,468 x$ Etkileşimci Liderlik $)+2,001$ 


\section{Dönüşümcü Liderlik Bağımsız Örgütsel Sessizlik Bağımlı Değişken Olmak Üzere Doğrusal Regresyon Analizi}

Tablo 13: Dönüşümcü Liderlik İle Örgütsel Sessizlik Arasındaki İlişkinin Derecesini Gösteren R. Değerinin Anlamlılığını Sınayan Varyans (Anova) Analizi

\begin{tabular}{lllllll}
\hline Model & & $\begin{array}{l}\text { Kareler } \\
\text { Toplam }\end{array}$ & Df & $\begin{array}{l}\text { Ort. } \\
\text { Kareler } \\
\text { Değeri }\end{array}$ & F & Sig. \\
\hline 1 & Regresyon & 30,512 & 1 & 30,512 & 27,141 & $000 \mathrm{~b}$ \\
& Artık Değer & 1206,241 & 1073 & 1,124 & & \\
& Toplam & 1236,753 & 1074 & & & \\
\hline
\end{tabular}

a. Bağımlı Değişken = Örgütsel Sessizlik

b. Yordayan $($ sabit $)=$ Dönüşümcü Liderlik

Tablodaki $\mathrm{p}$ değeri $(\mathrm{p}<, 01)$ göz önüne alındığında regresyon modelindeki, bağımlı değişken örgütsel sessizlik ile bağımsız değişken etkileşimci liderlik arasındaki ilişki için hesaplanan değerin $\left(R=-0,157^{* *}\right)$ istatistiksel olarak anlamlı olduğu görülmektedir.

Tablo 14: Dönüşümcü Liderlik İle Örgütsel Sessizlik Arasındaki İlişkiye Ait Regresyon Katsayıları Tablosu

\begin{tabular}{llllll}
\hline Model & $\begin{array}{l}\text { Standardize } \\
\text { Edilmemiş } \\
\text { katsayılar }\end{array}$ & Std.Hata & $\begin{array}{l}\text { Standardize } \\
\text { Edilmiş } \\
\text { Beta }\end{array}$ & $\mathrm{T}$ & Sig. \\
& B &, 133 & & 19,356 & 000 \\
1 (Sabit) & 2,580 &, 035 &, 157 & 5,210 & 000 \\
$\begin{array}{l}\text { Dönüşümcü } \\
\text { Liderlik }\end{array}$ &, 183 & & & & \\
\hline
\end{tabular}

Bağımlı Değişken: Örgütsel Sessizlik

Dönüşümcü liderliğin, örgütsel sessizliği ne şekilde yordadığını ortaya koymak için yapılan basit doğrusal regresyon analizi sonucunda, dönüşümcü liderlik ile örgütsel sessizlik arasında anlamlı ilişki olduğu gözlenmiş $(R=0,157 R 2=0,025)$, dönüşümcü liderliğin örgütsel sessizliğin bir yordayıcısı olduğu görülmüştür $(F(1-1073)=27,141 \mathrm{p}<0,01)$. Çalışmada yer verilen liderlik davranış türlerinden olan etkileşimci liderlik örgütsel sessizlikteki değişimin \%2'sini açıklamaktadır. Regresyon denkleminde esas yordayıcı değişkenin katsayısının $(B=0,183)$ anlamlılık testi de dönüşümcü liderliğin anlamlı bir yordayıcı olduğunu göstermektedir $(p<0,01)$. Regresyon analizi sonucuna göre, örgütsel sessizliği yordayan regresyon denklemi şu şekildedir: Örgütsel Sessizlik = (0,183x Dönüşümcü Liderlik $)+2,580$ 


\section{Örgütsel Sinizm Bağımlı Örgütsel Sessizlik Bağımsız Değişken Olmak Üzere Doğrusal Regresyon Analizi}

Tablo 15: Örgütsel Sinizm İle Örgütsel Sessizlik Arasındaki İlişkinin Derecesini Gösteren R. Değerinin Anlamlılığını Sınayan Varyans (Anova) Analizi

\begin{tabular}{lllllll}
\hline Model & & $\begin{array}{l}\text { Kareler } \\
\text { Toplam }\end{array}$ & Df & $\begin{array}{l}\text { Ort. } \\
\text { Kareler } \\
\text { Değeri }\end{array}$ & F & Sig. \\
\hline 1 & Regresyon & 849,711 & 1 & 849,711 & 1501,158 & $000 \mathrm{~b}$ \\
& Artık Değer & 607,358 & 1073 &, 566 & & \\
& Toplam & 1457,069 & 1074 & & & \\
\hline
\end{tabular}

a. Bağımlı Değişken = Örgütsel Sinizm

b. Yordayan (sabit) = Örgütsel Sessizlik

Tablodaki $p$ değeri $(p<, 01)$ göz önüne alındığında regresyon modelindeki, bağımlı değişken örgütsel sinizm ile bağımsız değişken olan örgütsel sessizlik arasındaki ilişki için hesaplanan değerin $\left(R=0,764^{* *}\right)$ istatistiksel olarak anlamlı olduğu görülmektedir.

Tablo 16: Örgütsel Sinizm İle Örgütsel Sessizlik Arasındaki İlişkiye Ait Regresyon Katsayıları Tablosu

\begin{tabular}{|c|c|c|c|c|c|}
\hline Model & $\begin{array}{l}\text { Standardize } \\
\text { Edilmemiş } \\
\text { katsayılar } \\
\text { B }\end{array}$ & Std.Hata & $\begin{array}{l}\text { Standardize } \\
\text { Edilmiş } \\
\text { Katsayılar } \\
\text { Beta }\end{array}$ & $\mathrm{T}$ & Sig. \\
\hline 1 (Sabit) & ,341 & , 073 & & 4,651 & 000 \\
\hline $\begin{array}{l}\text { Örgütsel } \\
\text { Sessizlik }\end{array}$ & 829, & ,021 & 764 & 38,745 & 000 \\
\hline
\end{tabular}

Bağımlı Değişken: Örgütsel Sinizm

Bağımsız değişken olan örgütsel sessizliğin, örgütsel sinizmi ne şekilde yordadığını ortaya koymak için yapılan basit doğrusal regresyon analizi sonucunda, örgütsel sessizlik ile örgütsel sinizm arasında anlamlı ilişki olduğu gözlenmiş $(R=0,764 R 2=0,583)$, örgütsel sessizliğin örgütsel sinizmin bir yordayıcısı olduğu görülmüştür $(F(1-1073)=1501,158 p<0,01)$. Çalışmada yer verilen örgütsel sessizlik örgütsel sinizmdeki değişimin $\% 58$ 'ini açıklamaktadır. Regresyon denkleminde esas yordayıcı değişkenin katsayısının $(B=0,829)$ anlamlılık testi de örgütsel sessizliğin anlamlı bir yordayıcı olduğunu göstermektedir $(\mathrm{p}<0,01)$.

Regresyon analizi sonucuna göre, örgütsel sessizliği yordayan regresyon denklemi şu şekildedir: Örgütsel Sinizm $=(0,829 x$ Örgütsel Sessizlik $)+0,341$ 


\section{Örgütsel Sinizm Bağımsız, Psikolojik İyi Oluş Bağımlı Değişken Olmak Üzere Doğrusal Regresyon Analizi}

Tablo 17: Örgütsel Sinizm İle Psikolojik İyi Oluş Arasındaki İlişkinin Derecesini Gösteren R. Değerinin Anlamlılığını Sınayan Varyans (Anova) Analizi

\begin{tabular}{lllllll}
\hline Model & & $\begin{array}{l}\text { Kareler } \\
\text { Toplam }\end{array}$ & Df & $\begin{array}{l}\text { Ort. } \\
\text { Kareler } \\
\text { Değeri }\end{array}$ & F & Sig. \\
\hline 1 & Regresyon & 9,217 & 1 & 9,217 & 9,930 & $000 \mathrm{~b}$ \\
& $\begin{array}{l}\text { Artık Değer } \\
\text { Toplam }\end{array}$ & 995,914 & 1073 &, 928 & & \\
\hline
\end{tabular}

a. Bağımlı Değişken = Psikolojik İyi Oluş

b. Yordayan (sabit) = Örgütsel Sinizm

Tablodaki $\mathrm{p}$ değeri $(\mathrm{p}<, 01)$ göz önüne alındığında regresyon modelindeki, bağımlı değişken örgütsel sinizm ile bağımsız değişken olan örgütsel sessizlik arasındaki ilişki için hesaplanan değerin $\left(R=-0,096^{* *}\right)$ istatistiksel olarak anlamlı olduğu görülmektedir.

Tablo 18: Örgütsel Sinizm İle Psikolojik İyi Oluş Arasındaki İlişkiye Ait Regresyon Katsayıları Tablosu

\begin{tabular}{llllll}
\hline Model & $\begin{array}{l}\text { Standardize } \\
\text { Edilmemiş } \\
\text { katsayılar }\end{array}$ & Std.Hata & $\begin{array}{l}\text { Standardize } \\
\text { Edilmiş } \\
\text { Katsayılar } \\
\text { Beta }\end{array}$ & T & Sig. \\
& B &, 082 & & 51,464 & .000 \\
1 (Sabit) & 4,226 &, 025 &,- 096 & $-3,151$ & .002 \\
$\begin{array}{l}\text { Örgütsel } \\
\text { Sinizm }\end{array}$ &,- 080 & & & & \\
\hline
\end{tabular}

Bağımlı Değişken: Psikolojik İyi Oluş

Bağımsız değişken olan örgütsel sessizliğin, örgütsel sinizmi ne şekilde yordadığını ortaya koymak için yapılan basit doğrusal regresyon analizi sonucunda, örgütsel sinizm ile psikolojik iyi oluş arasında anlamlı ilişki olduğu gözlenmiş $(R=-0,087 R 2=0,009)$, örgütsel sinizmin psikolojik iyi oluşun bir yordayıcısı olduğu görülmüştür (F (1-1073)=9,930 p<0,01). Çalışmada yer verilen örgütsel sinizm, psikolojik iyi oluştaki değişimin \%1'ini açılamaktadır. Regresyon denkleminde esas yordayıcı değişkenin katsayısının $(B=-, 080)$ anlamlılık testi de örgütsel sinizmin anlamlı bir yordayıcı olduğunu göstermektedir $(p<0,01)$.

Regresyon analizi sonucuna göre, örgütsel sessizliği yordayan regresyon denklemi şu şekildedir: Psikolojik İyi Oluş= (- 0,080x Örgütsel Sinizm $)+4,226$ 


\section{TARTIŞMA, SONUÇ VE ÖNERILER}

Araştırmada liderlik türlerinden olan etkileşimci ve dönüşümcü liderliğin örgütsel sessizlik, örgütsel sinizm ve psikolojik iyi oluş ile arasında olan ilişki araştırılmıştır. Çalışma bulgularından yola çıkarak araştııılmış olan popülasyonu temsilen konaklama işletmeleri çalışanlarında meydana gelen örgütsel sessizlik üzerinde liderlik türlerinden olan etkileşimci $(R 2=0,109)$ ve dönüşümcü $(R 2=0,025)$ liderliğin etkisinin olduğu düşünülmektedir. Yapılan analiz sonucunda diğer değişkenlerden olan örgütsel sessizliğinin örgütsel sinim $(R 2=0,583)$ örgütsel sinizmin ise psikolojik iyi oluş $(R 2=0,009)$ üzerinde etkisi olduğu tespit edilmiştir.

Çalışmada etkileşimci liderlik ( $\left.R=330^{* *}\right)$ dönüşümcü liderlik $\left(R=157^{* *}\right)$ ile örgütsel sessizlik değişkenleri arasında da doğrusal bir ilişkinin varlığı kendisini göstermektedir. Önceki çalışmalarda (Erol ve Köroğlu, 2013; Kılıç vd., 2014; Çatır ve Ünlüönen, 2015) bahsedilen dönüşümcü liderlik ve örgütsel sessizlik ilişkisine nazaran bu çalışmada iki değişken arasında ortaya çıkan pozitif yönlü doğrusal ilişki çalışmada farklılık olarak ortaya çıkmıştır. Bunun nedeni olarak ne kadar destekleyici olursa olsun örgüt içinde bir liderin varlığının olması gösterilebilir. Çalışan personel, kararları genellikle kendisi veren, ödül-ceza sistemi ile çalışan, katı kuralları olan bir lidere sahip olduğunda işten atılma, negatif geri bildirim, ceza alma gibi korkular ile örgüt içinde sessiz kalırken, liderinin destekleyici, yol gösterici olması durumunda da itaatsizlik etmemek, güvensizlik aşılamamak için de sessiz davranabilir.

Çalışmanın devamında örgütsel sessizlik ile örgütsen sinizm arasında $\left(R=764^{* *}\right)$ orta seviyede doğrusal yönlü bir ilişki tespit edilirken, örgütsel sinizm ile psikolojik iyi oluş arasında doğrusal yönlü olmayan zayıf bir ilişki $\left(R=-096^{* *}\right)$ olduğu belirlenmiştir. Ayrıca araştırmaya katılan personelin eğitim durumları incelendiğinde, İtalya'da çalışan turizm personelin eğitim durumlarının daha yüksek olması da çalışmanın diğer sonuçları arasındadır.

Yönetici, sahip olduğu liderlik vasfını çalışan personel lehine ve etkili bir biçimde gösteremediği zaman örgütsel sessizlik, örgütsel sinizm ve psikolojik iyi oluş kavramlarının örgüt içinde olumsuz şekilde kendisini göstermesi kaçınılmazdır. Bu yüzden bu değişkenlerin konaklama işletmeleri için kritik önem taşıyabileceği düşünülebilir. Çalışmanın, olumlu liderlik davranışları göstererek, örgütsel sessizlik ve sinizmi kaldırmak, çalışanın sahip olduğu psikolojik iyi oluşu olumlu yönde etkilemek isteyen işletme yöneticilerine, hangi liderlik davranış türlerini benimsemeleri gerektiği konusunda uygulamaya dönük, yol gösterici bir bakış açısı sergileyeceği düşünülmektedir.

Literatürde daha önce ayrı ayrı bu konular üzerinde yapılmış birçok çalışmaya rastlanırken, konuya ilişkin merakın giderilmesine yönelik Türkçe ve yabancı yazında çeşitli araştırmalar yapılmasına rağmen bahsedilen beş değişkenin konu edinildiği bir çalışmaya daha önce rastlanılmamıştır. Ele alınan liderlik, örgütsel sessizlik, örgütsel sinizm ve psikolojik iyi oluş kavramlarının örgütte ortaya çıktığı andan itibaren birbirinin devamı niteliğinde olmasından dolayı buna benzer çalışmalara ağırlık verilmesi ve yapılan çalışmaların birbiri ile karşılaştırılarak konuya yeni boyutlar kazandırılması ilgili literatüre katkı sağlanması açısından önemli olarak görülmektedir.

Çalışmada ele alınan liderlik, örgütsel sessizlik, örgütsel sinizm ve psikolojik iyi oluş kavramları örgütte ortaya çıktığı andan itibaren birbirinin devamı niteliğinde olmasından dolayı literatürde buna benzer çalışmalara ağırlık verilmesi ve yapılan çalışmaların birbiri ile karşılaştırılarak konuya yeni boyutlar kazandırılmasının yazına katkı sağlayacağı düşünülmektedir.

Çalışmada kişilerin objektifliği varsayımı çerçevesinde sonuçlar değerlendirildiğinden bu konu çalışmanın önemli bir sınırlılığı olarak düşünülmektedir. Demografik özelliklerin kontrol altına alınmadan ilişkinin değerlendirilmesi ise yine ayrı bir kısıt olarak görülmektedir. Diğer bir ifade 
ile çalışma dışında kalan farklı değişkenlerde, çalışmada yer alan değişkenler üzerinde etkili olabilir. Dolayısıyla ilerideki çalışmaların farklı değişkenler çerçevesinde ve bahsedilen değişkenleri bütüncül bir bakış açısıyla ele alarak farklı popülasyonlardan elde edilecek verilerle değerlendirilmesinin alana katkı sağlayacağına inanılmaktadır.

\section{KAYNAKÇA}

Aksu, G. (2012). Takım Liderinin Çalışanların Motivasyonu Üzerindeki Etkisi: Çağrı Merkezi İncelemesi, Akademik Bakış Dergisi, 32: 1-21.

Altınöz, M. Çakıroğlu, D. Çöp, S. ve Kahraman, E. (2017). Örgütsel Sessizliğin Örgütsel Sinizm Üzerine Etkisi: Bir Alan Araştırması, Electronic Journal of Vocational Colleges, 7 (2): 73-79.

Ariyabuddhiphongs, V. and Kahn, S. I. (2017). Transformational Leadership and Turnover Intention: The Mediating Effects of Trust and Job Performance on Cafe Employees in Thailand, Journal of Human Resources in Hospitality and Tourism, 16 (2): 215-233.

Avey, J. B. Wernsing, T. S. and Luthans, F. (2008). Can Positive Employees Help Positive Organizational Change? Impact of Psychological Capital and Emotions on Relevant Attitudes and Behaviors, The Journal of Applied Behavioral Science, (44) 1: 48-70.

Bakan, İ ve Büyükbeşe, T. (2010). Liderlik Türleri ve Güç Kaynaklarına İlişkin Mevcut-Gelecek Durum Karşılaştırması: Eğitim Kurumu Yöneticilerinin Algılarına Dayalı Bir Alan Araştırması, Karamanoğlu Mehmetbey Üniversitesi Sosyal ve Ekonomik Araştırmalar Dergisi, 12 (19): 73-84.

Bakhtawari, N. Z. Saeed, M. A. and Zaidi, E. (2016). Effect of Transformational Leadership Style on Choice of Strategy in Conflict Management in The Service Sector of Pakistan, Global Management Journal for Academic and Corporate Studies, 6 (2): 90.

Baltacı, F. Güçlü, A. G. C. ve Çeliker, A. G. N. (2014). Liderlik Davranışının Örgütsel Adalet Algısı ve İşten Ayrılma Niyeti Üzerine Etkileri: Konaklama İşletmelerinde Bir Uygulama, Süleyman Demirel Üniversitesi İktisadi ve İdari Bilimler Fakültesi Dergisi, 19 (3): 353-370.

Baltacı, F. Kavacık, M. Şentürk, F. K. ve Kurar, İ. (2014). Yöneticilerin Liderlik Özelliklerinin Çalışanların İş Tatmini Üzerindeki Etkisi: Alanya'da Bulunan 4 ve 5 Yıldızlı Otel Çalışanları Üzerine Bir Araştırma, Abant İzzet Baysal Üniversitesi Sosyal Bilimler Enstitüsü Dergisi, 14 (2): 59-85

Bass B. M. and Avolio B.J. (1995). Shatter The Glass Ceiling: Women May Make Better Managers, Human Resource Management, 33 (4): 549-560.

Brandes, P. Dharwadkar, R and Dean, J. W. (1999). Does Organizational Cynicism Matter? Employee and Supervisor Perspectives on Work Outcomes. The 36th Annual Meeting of the Eastern Academy of Management, Philadelphia, 1-33.

Can, H. (2014). Organizasyon ve Yönetim.(Dördüncü Baskı). Ankara: Siyasal Kitabevi.

Çakıcı, A. (2007). Örgütlerde Sessizlik: Sessizliğin Teorik Temelleri ve Dinamikleri, Çukurova Üniversitesi Sosyal Bilimler Enstitüsü Dergisi, 16 (1): 145-162.

Çatır, O ve Ünlüönen, K. (2015). Otel Çalışanlarının Dönüşümcü Liderlik Tarzına İlişkin Algılarının Belirlenmesine Yönelik Bir Araştırma, İşletme Araştırmaları Dergisi, 7 (3): 96-122.

Çokluk, Ö. Şekercioğlu G ve Büyüköztürk, Ş. (2010). Sosyal Bilimler İçin Çok Değişkenli İstatistik Spss ve Lisrel Uygulamaları. Ankara: Pegem Akademi,177.

Diener, E., Wirtz, D., Tov, W., Kim-Prieto, C., Choi, D. W., Oishi, S and Biswas-Diener, R. (2010). New Well-Being Measures: Short Scales to Assess Flourishing and Positive and Negative 
Feelings, Social Indicators Research, 97 (2): 143-156.

Dlamini. N.N.N., Garg, A.K and Muchie, M. (2017). The Impact of Transformational Leadership Style on Organizational Commitment in The Hospitality Industry, African Journal of Hospitality, Tourism and Leisure, 6 (3): 1-21.

Erol, G ve Köroğlu, A. (2013). Liderlik Tarzları ve Örgütsel Sessizlik İlişkisi: Otel İşletmelerinde Bir Araştırma, Seyahat ve Otel İşletmeciliği Dergisi,10 (3): 45-64.

Ertürk, M. (2013). İşletmelerde Yönetim ve Organizasyon (Yedinci Bask1). İstanbul: Beta Basım, 173-179.

Güzel, T ve Akgündüz, Y. (2011). Liderlik Davranışlarının Orta Düzey Yöneticiler Üzerindeki Etkisi ve Yöneticilerin Tükenmişlik Düzeyleri İle İlişkisi; Kuşadası Otel İşletmelerinde Bir Araştırma, Yönetim Bilimleri Dergisi, 9 (2): 283-296.

Harms, P. D., Crede, M., Tynan, M., Leon, M and Jeung, W. (2017). Leadership and Stress: A MetaAnalytic Review, The Leadership Quarterly, 28 (1): 178-194.

Izgar, H. (2008). Okul Yöneticilerinde İş Doyumu ve Örgütsel Bağlll1k, Ahmet Keleşoğlu Eğitim Fakültesi Dergisi. (25): 317 -334.

James, M. (2005). Antecedents and Consequences of Cynıcısm in Organızatıons: An Examınation of the Potential Positive and Negative Effects on School Systems. (Dissertation of Doctor of Philosophy). The Florida State University, Florida.

Keyes, C. L. M. Shmotkin, D. and Ryff, C. D. (2002). Optimizing Well-Being: The Empirical Encounter of Two Traditions, Journal of Personality and Social Psychology, 82 (6): 1007-1022.

Kılıç, R. Keklik, B ve Yıldız, H. (2014). Dönüştürücü, Etkileşimci ve Tam Serbestlik Tanıyan Liderlik Tarzlarının Örgütsel Sessizlik Üzerindeki Etkisini Belirlemeye Yönelik Bir Araştırma, Journal of Management and Economics, 21 (2): 249-268.

Luo, Z., Marnburg, E and Law, R. (2017). Linking Leadership and Justice to Organizational Commitment: The Mediating Role of Collective Identity in The Hotel Industry, International Journal of Contemporary Hospitality Management, 29 (4): 1167-1184.

Morçin, S. E ve Bilgin, N. (2014). Dönüştürücü Liderliğin Örgütsel Bağlllığa Etkisi: Adana İlindeki A Grubu Seyahat Acenteleri Örneği, Çukurova Üniversitesi Sosyal Bilimler Enstitüsü Dergisi, 23 (2): 113-128.

Ohunakin, F., Adeniji, A. A. and Akintayo, I. D. (2016). Transactional Leadership Style and Employee Job Satisfaction Among Universities' Guest Houses in South-West Nigeria. Third International Conference on African Issues.368-371.

Özdemir, L ve Uğur, S. S. (2013). Çalışanların Örgütsel Ses ve Sessizlik Algılamalarının Demografik Nitelikler Açısından Değerlendirilmesi: Kamu ve Özel Sektörde Bir Araştırma, Atatürk Üniversitesi İktisadi ve İdari Bilimler Dergisi, 27 (1): 257-281.

Piderit, S.K. and Ashford, S.J. (2003). Breaking Silence: Tactical Choices Women Managers Make in Speaking Up About Gender - Equity Issues, Journal of Management Studies, 40 (6): 14771502.

Polat, M ve Meydan, C. H. (2010). Örgütsel Özdeşleşmenin Sinizm ve İşten Ayrılma Niyeti İle İlişkisi Üzerine Bir Araştırma, Savunma Bilimleri Dergisi, 9 (1): 145-172.

Rachmawati, R. (2015). Transformational and Transactional Leadership Effect on Job Satisfaction in Santika Hotel, Bandung. In International Conference on Trends in Economics, Humanities and Management (ICTEHM'15), 27-28 March October 2015, Singapore, 57-62. 
Rothfelder, K., Ottenbacher, M. C and Harrington, R. J. (2012). The Impact of Transformational, Transactional and Non-Leadership Styles On Employee Job Satisfaction in The German Hospitality Industry, Tourism and Hospitality Research, 12 (4): 201-214.

Ryff, C. D (1989). Happiness Is Everything, Or Is It? Explorations on The Meaning of Psychological Well-Being, Journal of Personality and Social Psychology, 57 (6): 1069-1081.

Sığrı, Ü ve Gürbüz, S. (2014). Örgütsel Davranış (İkinci Basım). İstanbul: Beta Basım, 32-38.

Spitzbart, I. (2013). The Impact of Transactional Versus Transformational Leadership on Job Satisfaction in The Hotel Industry, Research in Hospitality Management, 3 (1): 69-76.

Stanley, D. J. Meyer, J. P and Topolnytsky, L. (2005). Employee Cynicism and Resistance to Organizational Change, Journal of Business and Psychology, 19 (4): 429-459.

Tanrıverdi, H, Akova, O. ve Çifçi, İ. (2016). Açılış-Otellerinde Dönüşümcü, Etkileyici, Tam Serbestlik Tanıyan Liderlik Tarzlarının ve Çatışma Yönetim Stillerinin İşten Ayrılma Niyeti Üzerine Etkisi. KMÜ Sosyal ve Ekonomik Araştırmalar Dergisi, 18 (30): 114-123. 